\title{
AREA REDUCTIONASTER MEASUREMENTS OF FRACTURED TENSILE SPECIMENS
}

\section{NUCLEAR AEROSPACE RESEARCH FACILITY}




\section{DISCLAIMER}

This report was prepared as an account of work sponsored by an agency of the United States Government. Neither the United States Government nor any agency Thereof, nor any of their employees, makes any warranty, express or implied, or assumes any legal liability or responsibility for the accuracy, completeness, or usefulness of any information, apparatus, product, or process disclosed, or represents that its use would not infringe privately owned rights. Reference herein to any specific commercial product, process, or service by trade name, trademark, manufacturer, or otherwise does not necessarily constitute or imply its endorsement, recommendation, or favoring by the United States Government or any agency thereof. The views and opinions of authors expressed herein do not necessarily state or reflect those of the United States Government or any agency thereof. 


\section{DISCLAIMER}

Portions of this document may be illegible in electronic image products. Images are produced from the best available original document. 


\section{NUCLEAR AEROSPACE RESEARCH FACILITY}

\section{AREA REDUCTION MEASUREMENTS OF} FRACTURED TENSILE SPECIMENS

Prepared for AEROJET-GENERAL CORPORATION
SACRAMENTO, CALIFORNIA

This report was prepared a an account of work
sponsored by the United States Government. Neither
the United States nor the United States Energy
Research and Development Administration, nor any of
their employees, nor any of their contractors,
subcontractors, or their employees, makes any
warranty, express or implied, or assumes any legal
liability or responsibility for the accuracy, completeness
or usefulness of any information, apparatus, product or
process disclosed, or represents that its use would not
infringe privately owned rights.

AGC PO Number NP-000128, Item 3

\section{GENERAL DYNAMICS}

Fort Worth Division 


\section{SUMMARY}

Magnified photographs were taken of selected AGC fractured tensile test specimens located at NARF. The specimens were from GTR-16 and previous tests. Cross-sectional areas of the fractured edges of the specimens were then measured with a planimeter, reduced by the magnification factor, and recorded. A total of 140 specimens were photographed and measured. The specimens were fabricated from the following materials:

$$
\begin{aligned}
& \mathrm{A}-286 \\
& \mathrm{~A} 1-356-\mathrm{T} 6 \\
& \mathrm{~A} 1-6061-\mathrm{T} 6 \\
& \mathrm{~A} 1-7075-\mathrm{T} 6 \\
& \text { Haste11oy C } \\
& \text { Incone1 } 713-\mathrm{C} \\
& \text { Incone1 X-750 } \\
& \text { SS-347-C } \\
& \mathrm{Ti}-\mathrm{A}-110-\mathrm{AT}
\end{aligned}
$$

An average of four measurements was used to determine the fractured areas. All data obtained in the tests are shown in Table 3.1. 


\section{I . INTRODUCTION}

Both the original cross-sectional area of untested specimens and the reduced cross-sectional area of fractured specimens were determined previously for a11 AGC specimens located at NARF。 Tris data, which were obtained with a micrometer, were submitted pre* viously to AGC in accordance with contractual requirements.

More accurate values of the reduced cross-sectional areas are now required by $A G C$ and were obtained in this test. The approach involved taking a magnified photograph of the fracturea edge of the specimen, and measuring its cross-sectional area with a planimeter. 


\section{TEST PROCEDURES}

The specified tensile test specimens were removed from storage and prepared for photography. The two halves, when both were avaiI = able, were taped together to allow the two fractured edges to be adjacent in the photograph. A Bausch \& Lomb Optical Co., Mode1 L, camera was utilized, employing a 4 x 5 Polaroid film holder. Type 57 Polaroid film was used. An optimum camera setting to allow fuil use of the exposure surface was determined and secured. The result. ing magnification factor ranged from 7.15 to 7.18 . Included in each photograph was a scale having 0.01-in. increments. The magnification factor was verified, using the photographed scale, for each specimen. The camera setting remained constant during all photow graphs; however, some focusing was required due to some extreme angles of specimen fracture.

Mr. John Bauer, Aerojet General Corporation, reviewed each photo as it was obtained, recorded the individual specimen number on the print, and made other notations as needed.

Area measurements were accomplished by use of a planimeter, Keuffel \& Esser Co., Model 4236. Two measurements of each half were made and an average of the four values obtained. To ensure good accuracy in the measurements, the planimeter tracing was viewed through a 2-power magnifying glass.

The average area, as measured, was reduced by the photograph magnification factor to yield the correct fractured area of each individual test specimen. 


\section{TEST RESULTS}

The reduced cross-sectional areas of the specimens were determined and values are tabulated in Table 3.1 . The test specimens are grouped in the table by material. The reported areas are an average of four measurements. 
Table 3.1

Reduced Cross-Sectional Areas of Tensile Specimens

\begin{tabular}{|c|c|c|c|}
\hline $\begin{array}{l}\text { Material and } \\
\text { Specimen No. }\end{array}$ & $\begin{array}{l}\text { Reduced Cross- } \\
\text { Sectional Area } \\
\left(\ln ^{2}\right)\end{array}$ & $\begin{array}{l}\text { Material and } \\
\text { Specimen No. }\end{array}$ & $\begin{array}{c}\text { Reduced Cross- } \\
\text { Sectional Area } \\
\left(\text { in }^{2}\right)\end{array}$ \\
\hline $\begin{array}{l}6061-\mathrm{T} 6 \\
2-74 \\
2-77 \\
2-78 \\
2-79 \\
2-80 \\
2-84 \\
3-25 \\
3-26 \\
3-27 \\
3-28 \\
3-29 \\
3-30 \\
3-31 \\
3-32 \\
3-33 \\
3-34 \\
3-35 \\
3-36 \\
3-73 \\
3-74 \\
3-75 \\
3-76 \\
3-77 \\
3-78 \\
3-79 \\
3-80 \\
3-82 \\
3-83 \\
3-97 \\
3-98 \\
3-99 \\
3-100 \\
3-101 \\
3-102 \\
3-106 \\
3-1115 \\
3-116 \\
3-117\end{array}$ & $\begin{array}{l}.0281 \\
.0307 \\
.0295 \\
.0311 \\
.0293 \\
.0281 \\
.0301 \\
.0299 \\
.0339 \\
.0306 \\
.0360 \\
.0350 \\
.0313 \\
.0349 \\
.0346 \\
.0336 \\
.0366 \\
.0321 \\
.0316 \\
.0311 \\
.0304 \\
.0310 \\
.0407 \\
.0366 \\
.0385 \\
.0342 \\
.0383 \\
.0383 \\
.0239 \\
.0271 \\
.0243 \\
.0259 \\
.0338 \\
.0289 \\
.0286 \\
.0264 \\
.0263 \\
.0274\end{array}$ & $\begin{array}{c}6061-\mathrm{T} 6 \\
3-118 \\
3-119 \\
3-120 \\
3-265 \\
3-267 \\
3-268 \\
3-269 \\
3-275 \\
3-281 \\
3-283 \\
3-285 \\
\mathrm{R}-82 \\
\mathrm{R}-83 \\
\mathrm{R}-84 \\
717 \\
718 \\
719 \\
720 \\
724 \\
725 \\
726 \\
760 \\
761 \\
70 \\
7075-\mathrm{T} 6 \\
2-101 \\
2-102 \\
2-104 \\
2-105 \\
2-106 \\
2-107 \\
2-108 \\
\\
\mathrm{~A}-356 \\
2-1 \\
2-2 \\
2-3 \\
2-4\end{array}$ & $\begin{array}{l}.0260 \\
.0260 \\
.0271 \\
.0370 \\
.0300 \\
.0302 \\
.0332 \\
.0378 \\
.0382 \\
.0370 \\
.0361 \\
.0267 \\
.0278 \\
.0404 \\
.0413 \\
.0417 \\
.0414 \\
.0413 \\
.0418 \\
.0398 \\
.0430 \\
.0436 \\
.0281 \\
\\
.0443 \\
.0404 \\
.0438 \\
.0418 \\
.0413 \\
.0418 \\
.0414 \\
.044 \\
.0443 \\
.0442 \\
.0438 \\
.0439\end{array}$ \\
\hline
\end{tabular}


Table 3.1 (Cont'd)

\begin{tabular}{|c|c|c|c|}
\hline $\begin{array}{l}\text { Material and } \\
\text { Specimen No. }\end{array}$ & $\begin{array}{l}\text { Reduced Cross- } \\
\text { Sectional Area } \\
\left(\text { in }^{2}\right)\end{array}$ & $\begin{array}{l}\text { Material and } \\
\text { Specimen No. }\end{array}$ & $\begin{array}{l}\text { Reduced Cross- } \\
\text { Sectional Area } \\
\left(\text { in }^{2}\right)\end{array}$ \\
\hline $\begin{array}{l}\text { A-356 } \\
2-5 \\
2-6 \\
2-8 \\
2-9 \\
2-10 \\
2-11 \\
\text { A-I10 } \\
2-280 \\
2-281 \\
2-282 \\
2-284 \\
2-285 \\
2-286 \\
2-287 \\
2-288 \\
2-293 \\
2-294 \\
2-295 \\
2-297 \\
2-299 \\
2-300 \\
\\
\text { Inconel } \\
\text { X750 } \\
2-377 \\
2-378 \\
2-379 \\
2-380 \\
2-381 \\
2-382 \\
2-383 \\
\text { Incone1 } \\
713-C \\
2-401 \\
2-402 \\
2-403 \\
2-404 \\
2-405 \\
2-406 \\
2-407\end{array}$ & $\begin{array}{l}.0443 \\
.0428 \\
.0442 \\
.0442 \\
.0428 \\
.0441 \\
\\
.0256 \\
.0389 \\
.0361 \\
.0368 \\
.0389 \\
.0356 \\
.0352 \\
.0352 \\
.0398 \\
.0399 \\
.0410 \\
.0385 \\
.0428 \\
.0431 \\
\\
\\
.0325 \\
.0313 \\
.0316 \\
.0328 \\
.0309 \\
.0318 \\
.0313 \\
\\
.0320 \\
.0449 \\
.0418 \\
.0371 \\
.0423 \\
.0427 \\
.0403\end{array}$ & $\begin{array}{c}\text { SS } 347 \\
2-173 \\
2-174 \\
2-175 \\
2-177 \\
2-178 \\
2-179 \\
2-180 \\
3-197 \\
3-198 \\
3-199 \\
3-200 \\
3-201 \\
3-202 \\
3-204 \\
701 \\
703 \\
704 \\
\\
\text { A-286 } \\
2-205 \\
2-207 \\
2-208 \\
2-209 \\
2-210 \\
2-211 \\
2-213 \\
2-214 \\
2-215 \\
2-216 \\
\\
\text { Haste } \\
\text { C } \\
2-30 y \\
2-354 \\
2-355 \\
2-356 \\
2-357 \\
2-358 \\
2-360\end{array}$ & $\begin{array}{l}.0393 \\
.0410 \\
.0400 \\
.0399 \\
.0414 \\
.0434 \\
.0424 \\
.0272 \\
.0256 \\
.0363 \\
.0268 \\
.0281 \\
.0270 \\
.0272 \\
.0293 \\
.0302 \\
.0304 \\
\\
.0335 \\
.0285 \\
.0272 \\
.0282 \\
.0278 \\
.0300 \\
.0291 \\
.0293 \\
.0329 \\
.0295\end{array}$ \\
\hline
\end{tabular}


SNPO-Cleveland

Lewis Research Center

21000 Brookpark Road

Cleveland 35, Ohio

Attn: E. W. Miller

Aerojet General Corporation

P. O. Box 1947

Sacramento, California

Attn: W. A. Greenhow

(5)

Aerojet General Corporation

P. O, Box 1947

Sacramento, California

Attn: J. R。 Kaney

(1) 